ークなどの解析も実施し適合ウェー八条件を検討している。

素子工程での污染の影響を減ずるために鏡面ウェー八の裏面に サンドブラスト等で加工損傷（ダメージ）をあたえ，污染不純物 をその䄳の場にゲッターさせる extrinsic getter 法や, 鏡面ウェ 一八を低温と高温で熱処理し，内部に微小久樎を作り集合させて 欠陥の歪の場にゲッターさせる intrinsic gettering用のウェー 八も製造している。

$\mathrm{Si}$ の欠陥等については透過型電子顕微鏡 $(200 \mathrm{kV})$ や強力X線 (RU500) による解析などの物性的研究や, 不純物, 污染等につ いてオージェ分光， I M A, S E M, 放射化分析等の評価技術に より三菱金属中央研究所と協同研究を行なつている。

\section{$7 \cdot 2$ 太陽電池用基板結晶製造}

サンシャイソ計画推進本部の委託研究として昭和 49 年から実施 している。横引き法による Si 単結晶リボンの製造法で成長速度 $100 \mathrm{~mm} / \mathrm{min}$ ，幅 $40 \mathrm{~mm}$ のリボンが連続チャージ，連続成長で得
られる。

\section{$7 \cdot 3$ 高純度石英ガラスの合成}

東京大学工学部明石和夫教授の発明された方法を昭和 50 年より 開発事業団の委託研究として実用化研究を実施し, 昭和55年完成 した。製造工程は第 8 図のごとくで酸化水素焰を使用しないため, $\mathrm{OH}$ 基による $0.95,1.24,1.39 \mu \mathrm{m}$ 等の吸収が無く光通信用ファイ バーとしてもつとも低損失で，また放射線（中性子， $\gamma$ 線）による 透明度の劣化も少ない。

\section{8.むすび}

以上当社の製造全般について概要を述べたが，需要が活発なた め本年も設備増強を実施中である。また技術革新のもつとも急先 鋒である半導体素子の原料として三菱金属 (株)の強力なバックア ップのもとで，技術開発を集中的に押し進めるとともに合理化， 省エネルギー化をさらに推進させたい。

\title{
Production of Semiconductor Silicon at Japan Silicon Co.
}

\section{by Kiichiro MIZUMA}

Mitsubishi Metal Corporation (MMC) established Japan Electronic Metals Co., Ltd. (JEMCO), in 1959, which started production of high purity silicon and others as semiconductor materials. After, MMC purchased the stocks of Chisso Electronic Chemicals Co., Ltd., and synthesized it with JEMCO in 1978, MMC arranged all production facilities in Noda Factory, and Japan Silicon Co., Ltd. was newly started.

$$
\text { Capital: } ¥ 800,000,000
$$

Japan Silicon supplies its products to almost all of domestic semiconductor makers such as Mitsubishi Electric, Hitachi, Toshiba, and especially supplies most of silicon in need to Fujitsu which is famous for their computer FACOM series, and $100 \%$ of silicon in need to Sony which is famous as the electronics maker for consumer usage in the world.

High purity silicon is used as semiconductors for transistors, diodes, rectifiers, solar-cells, and integrated circuits (IC) including LSI (large scale integration). These devices are now very widely applied to such uses as color TV receivers, portable electronic calculators as well as large scale computers, control systems, including those for cars, and SCR (silicon controlled rectifier), in a wide range from family fans to electric cars for the super-express net work of the Japan National Railway.

Semiconductor industry has made a great progress in both quality and quantity. Business for supplying silicon materials is expected to grow rapidly and actively hereafter, too. Japan Silicon will increase capacity by $50 \%$ next year and invest steadily in the field of epitaxial wafers and junction isolated wafers which are the high added value materials.

\section{〔4-14〕信越半導体(株)における高純度シリコンの製造}

\section{1. 緒} 言

信越半導体株式会社の前身は, 親会社信越化学工業株式会社の シリコン部門である。昭和 42 年 3 月には, 昭和 36 年以来企業とし て手がけてきた半導体シリコン製造部門を別会社として分離独立 せしめ, 同時に米国ダウ・コーニング社との合弁会社として発足 した。昭和 54 年には, ダウ・コーニング社が, 多結晶シリコンの 生産に集中することになり, 合弁企業を解消して信越化学 $100 \%$ の子会社になつた。発足当初より，技術の諸部門は信越半導体側 担当者があたつてきたが，ここにきて名実とも日本を代表するシ リコンウェーハメーカになつたのである。

シリコンウェー八生産の初期には, 電気メーカが, それぞれ, 自ら単結晶を製造し，それを素材として半導体素子を製造してい たが，半導体市場の急激な拡大，より高い品質，より䈌しい規格 などが要求されるようになつて, 次第に専業化するようになり,

\section{1. 信越半導体株式会社半導体研究所新製品開発室長}

\section{吉田尚 達 ${ }^{1}$}

今日では, 国内 5 社 (日本シリコン, 大阪チタニウム, 小松電子 金属, 東芝セラミックス, 信越半導体) がほとんどの半導体シリ コンの生産, 供給を受け持つようになつている。特に, 従来鏡面 ウェー八までの生産が主業であつたが, 最近では, 加工度を一歩 高め, デバイスメーカの一部の工程, 例えば, シリコンエピタキ シャルウェーハ, トランジスタの基板であるコレクター拡散ウェ 一八, バイポーラ I C の基板である埋込み拡散ウェー八の生産ま で手がけるようになつた。

昭和 42 年, 信越半導体設立当初は, 群馬県安中市の磯部工場の みで発足したが, その後の急激な需要の増加に応えるために福井 県武生市に武生工場, 新潟県上越市に直江津工場が設置された。 磯部工場では, $\mathrm{CZ}$ 単結晶, F Z 単結晶, エピタキシャルウェー 八，化合物半導体の部門をもち，また武生工場，直江津工場はそ れぞれ C Z 単結晶, 多結晶の専門工場である。ウェーハ加工は, 関連会社である直江津電子工業株式会社 (新潟県) と長野電子工 業株式会社 (長野県) で尃門加工を行なつており，さらに海外に 

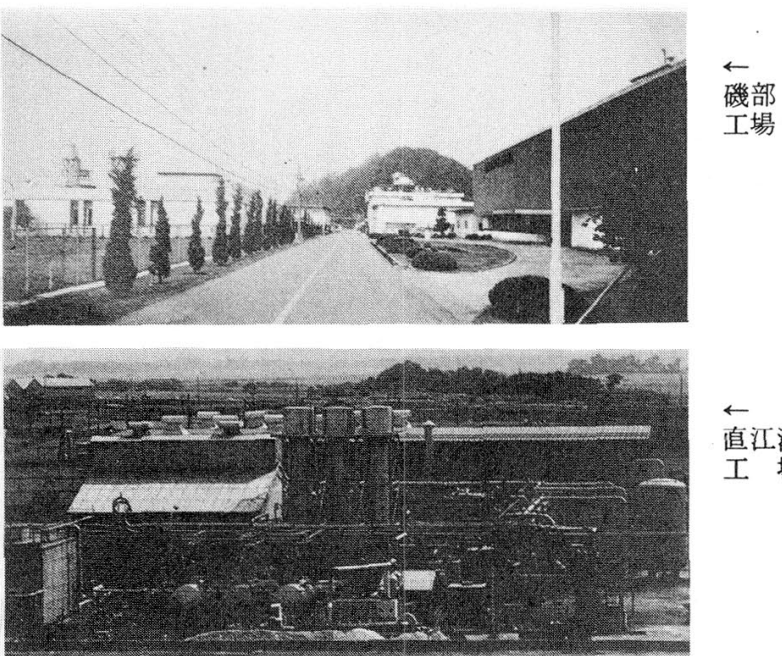

直江津 工 場

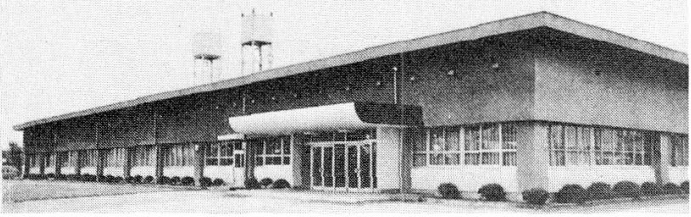

武生 工場

\section{第1図工場全景}

に打ける加工会社として, 信越半導体 $100 \%$ 出資のSEH マレーシ ヤ工場が設置され, 内需および輸出向け製品の生産に有機的役割 を果している。

昭和 43 年以後 10 数年, シリコン単結晶の生産量は年々増加して きたが，デバイスメーカの急激な技術進歩に対応できるよう，ま た結晶技術に関しては一歩先んじるように，磯部工場に研究所を 設置して研究開発を進めてきた。創業当時は多結晶および $\mathrm{F} Z$ 法 単結晶技術はジーメンス (西独) 法によりスタートしたが, 現在 では結晶製造装置, 加工装置, 検查装置のほとんどは, 自社で開 発, 設計したものであり, 操業条件についても自社技術によるも のである。研究所から生み出された技術は製造のあらゆる領域に 及んでいるが，技術の進歩には上限がないことを念頭におき，業 界のニーズを一歩先取りし, さらに品質の向上, コストダウンを 目指し研究を進めている。

\section{2. シリコンウェーハの製造工程}

当社で現在行なつているシリコンウェー八の製造工程を示すと 第 2 図のとおりである。

\section{$2 \cdot 1$ トリクロロシラン}

珪石と木炭を電気炉で熱し, 還元して得られた金属珠素 ${ }^{a)}$ ( 純 度 $97 \sim 98 \%$ ) に塩化水素を反応させるとトリクロロシラン $\left(\mathrm{SiHCl}_{3}\right)$ が得られる。このトリクロロシランは精製されて, 親会社信越化 学より供給される。高品質の単結晶シリコンの製造には, 高純度 多結晶シリコンが必要であるが, そのためにはトリクロロシラン の純度が高いことが不可欠であり, 純度が確認されたトリクロロ シランのみ，多結晶シリコンの原料として用いる。

トリクロロシランは高度の蒸留技術, 多段の精留塔を多数本用 いる多段塔精留法を用いて精製される。各精留塔において, 高沸 点塩化シランと低沸点塩化ンランを抜きとり純度を確認しつつ精 留し, 精製された $\mathrm{SiHCl}_{3}$ は比色分析により， B,Pをガスクロマ

a) 第 1 次オイルショック以後電力料金の值上げにより金属理素の製造 を中止し，外国加の輸入に切替えた。

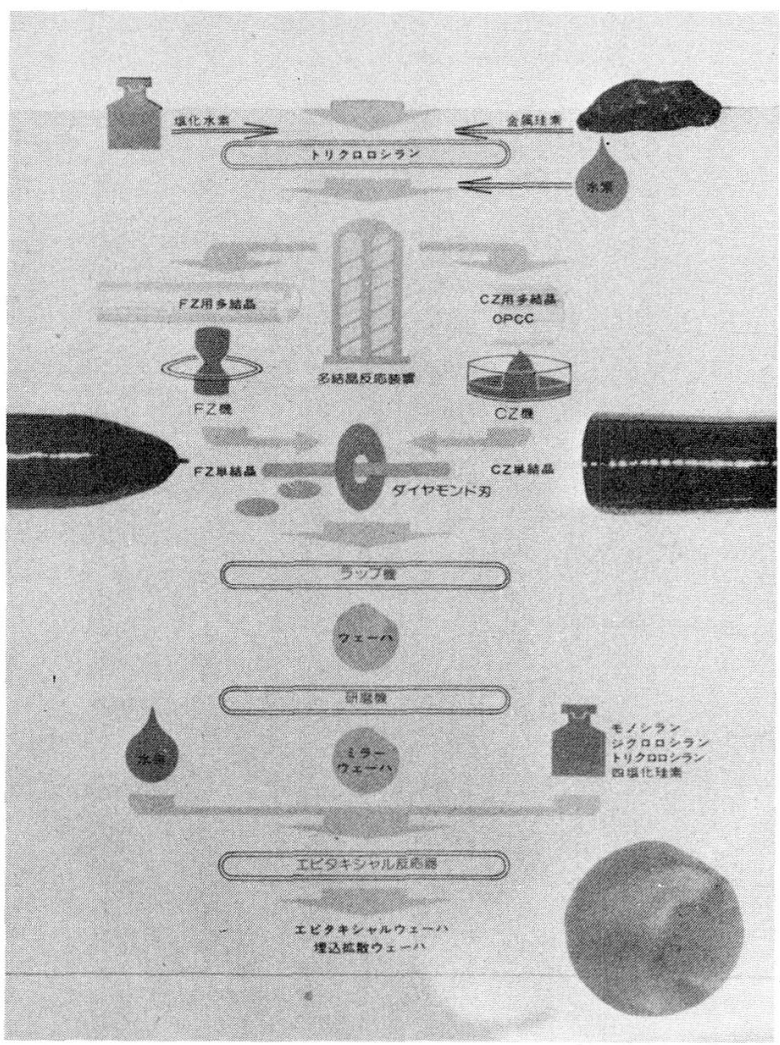

第2図シリコンウェーハの製造工程

トグラフィーにより, C, $\mathrm{SiCl}_{4}$ 等の不純物を定量分析してその純 度を確認する。純度の確認されたこのトリクロロシランバッチ は予備多結晶反応し, 単結晶化後, $\mathrm{P}$ 型 $5,000 \Omega \cdot \mathrm{cm}, \mathrm{N}$ 型 1,000 $\Omega \cdot \mathrm{cm}$ 以上, カーボン濃度 $0.1 \mathrm{ppma}$ 以下 (IRで測定), 重金属 はライフタイムにより間接的に求め $1,000 \mu \mathrm{sec}$ 以上であれば，合 格として多結晶シリコンの製造を開始する。

\section{$2 \cdot 2$ 多結晶シリコン}

第 3 図に示すような多結晶反応装置に細いシリコン芯棒をセッ トし，約 $1,100^{\circ} \mathrm{C}$ に加熱する。そこに気化したトリクロロシラン $\left(\mathrm{SiHCl}_{3}\right)$ と水素の混合ガスを送り达むと, 反応式

$\mathrm{SiHCl}_{3}+\mathrm{H}_{2} \rightarrow \mathrm{Si}+3 \mathrm{HCl}$

にもとづいて水素還元および熱分解して生成した純度の高いシリ コン微粒子が芯棒表面に析出して次第に太い棒状多結晶(第 4 図) が成長する。しかし, 実際には, 前記反応において, $\mathrm{SiCl}_{4}$, $\mathrm{SiH}_{2} \mathrm{Cl}_{2}, \mathrm{SiCl}_{2}$ 等の塩化シラン類を副生するが, これらは未反応 の $\mathrm{H}_{2}, \mathrm{SiHCl}_{3}$ とともに反応系外に取り出し, 精製して再度反応装 置に送り込むりサイクル方式をとつている。この方式により，

トリクロロシランのシリコンへの変換効率を高めている。

多結晶シリコンは, 次工程の単結晶化工程により，2 種類に分 けられる。一つはPoly rod と呼ばれる F Z 法による単結晶製造 用の多結晶棒で, そのまま F Z 機に装着し単結晶化する。口径は 使用する F Z 機に応じてさまざまであるが最近は直径 $100 \mathrm{~mm}$, 長 さが $1 \mathrm{~m}$ 前後のものも多くなつた。もう一つは C Z 用多結晶 (OPCC-One Piece Crucible Charge, 別名カットロッド) で あり，CZ引上げ機のルッボサイズ合わせて無䭾なく仕込みがで きるように切断して用いる。大型の多結晶反応装置では直径 150 $\mathrm{mm}$ 以上, 長さ $1.5 \mathrm{~m}$ 以上の結晶が製造されている。多結晶シリ コンは $2 \cdot 1$ に示した方法で純度を確認し, 合格した多結晶のみ 次の単結晶化工程に送り込む。

\section{$2 \cdot 3$ 単結晶化工程}

日本鉱業会誌/971122（'81-8） $887<287\rangle$ 

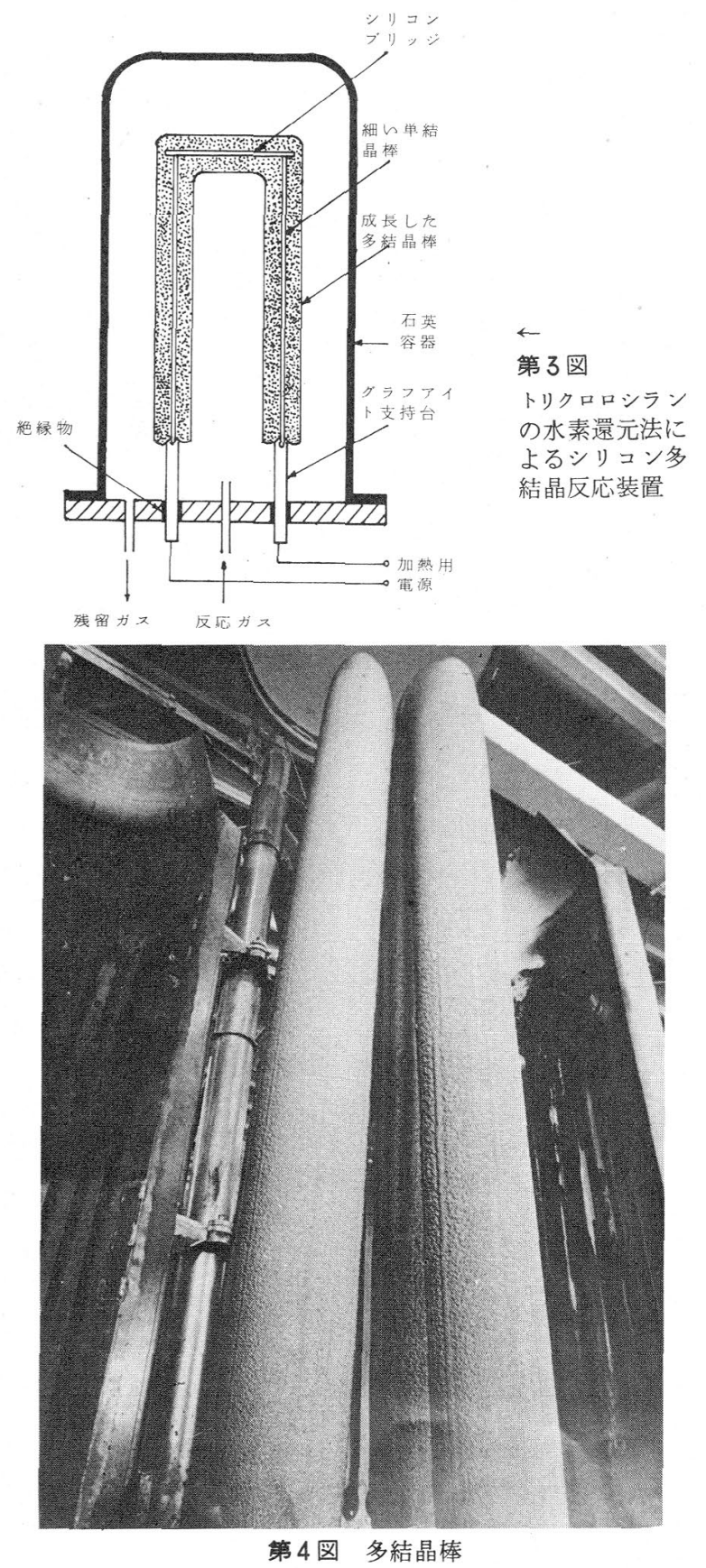

多結晶は半導体基板として使用できないため, 再溶融して結晶 方位を一定にした単結晶とする必要がある。融液からのンリコン 単結晶の成長法には 2 種類ある。その一つは $\mathrm{F} Z$ 法 (浮遊帯精法, Float Zoning ), もう一つは C Z 法 (引上げ法, Chochralski ) である。

$2 \cdot 3 \cdot 1$ ドーパント 純度 $100 \%$ のシコンは $260,000 \Omega$. $\mathrm{cm}$ も高い抵抗率を示す。これを適当な抵抗率まで引き下げなけ れば半導体として使用できない。また半導体してのもつとも重要 な性質である導電型を付与する必要がある。この導電型を決定し， かつ抵抗率をコントロール寸る物質としてごく微量の不純物を単 結晶化工程で添加するが，これをドーパント(ドープ剤) と呼ん でいる。ドーピング法は単結晶成長法により異なる。FZ法では 多結晶シリコンの芯にドーパントを添加しておく芯ドーピング法, 浮遊帯にガス状不純物化合物を添加するガスドーピング法および後 述する中性子照射によるドーピング法があり，またC Z 法ではシ
リコン融液にドーパント元素を添加する。

$\mathrm{P}$ 型のドーパントとしてボロン (B) ( 超高抵抗率 $10,000 \Omega \cdot \mathrm{cm}$ から超低抵抗率 $0.005 \Omega \cdot \mathrm{cm}$ まで)，N型のドーパントとしては, りん(P), アンチモン ( Sb)，七素( As ) の3 種類があるが, 後 二者は超低抵抗率 $(0.1 \sim 0.01 \Omega \cdot \mathrm{cm}$, 特に As の場合 $0.003 \Omega \cdot \mathrm{cm}$ までトげられる)の製造に使われる。ボロンは偏析係数（0.8）が 大きく結晶内で均一に分布するが, N 型の 3 種類のドーバントは 偏析係数 ( P : $0.35, \mathrm{Sb}: 0.023, \mathrm{As}: 0.3)$ が小さく不㚬一な分 布をつくりやすい。

たゆみない技術改良により，ドーパントの均一化は向上してき たが, 融液からの成長の場合限界がある。これを解消する方法と して, 現在特にドーパントの均一性を要求する単結晶の場合（ワ ンウェーハ・ワンデバイスのサイリスタ向けなど），中性子照射 (Neutron Bombardment法)によるドーピング法が行なわれてい る。これはドーパントを添加せずに F Z 法単結晶成長した後, 結 晶棒を原子炉内で中性子照射することにより, シリコン単結晶中 に $3 \%$ 程度含まれている同位元素 $\left({ }^{30} \mathrm{Si}\right)$ を直接りん $\left({ }^{31} \mathrm{P}\right)$ に変 換する方法 $\left[{ }^{30} \mathrm{Si}(n, \gamma) \rightarrow{ }^{31} \mathrm{P}+\beta^{-}\right]$で, 照射量を決めて目標の 抵抗率にするばかりでなく, ウェー八内できわめて均一な分布が 得られる (第 1 表参照)。

2・3・2 F Z 法単結晶の製造方法 F Z 法単結晶の成長し ているようすを第 5 図に示す。F Z 法は垂直に保持された多結晶 棒と種結晶（または成長した単結晶）の間に高周波加熱コイルで 融体層を形成し，この融体層を移動させて結晶棒を製造する方法 でありこの製造プロセスをつぎに示す。

多結晶棒の洗浄 $\rightarrow$ 多結晶棒をセット $\rightarrow$ 黒鉛または高融点金 属リングを高周波加熱 $\rightarrow$ 多結晶シリコンの高周波加熱 $\rightarrow$ 種つ $け \rightarrow$ 単結晶化開始 $\rightarrow$ 高周波パワー, 成長速度を調節しンーン 部の成長 $\rightarrow$ 直胴部の成長 $\rightarrow$ 単結晶を多結晶より切りはなす $\rightarrow$ 冷却 $\rightarrow$ 取出し $\rightarrow$ 中間検査 $\rightarrow$ 加工工程

$2 \cdot 3 \cdot 3 C$. Z 法罦結増の製造方法 原理はルッボ中にシリ

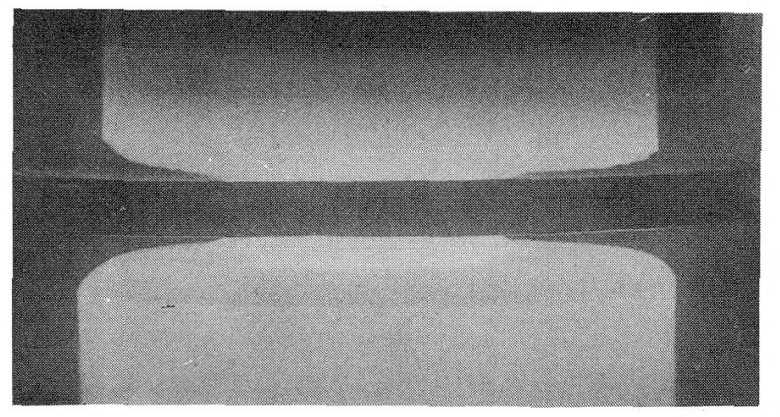

第 5 図 FZ法単結晶の成長

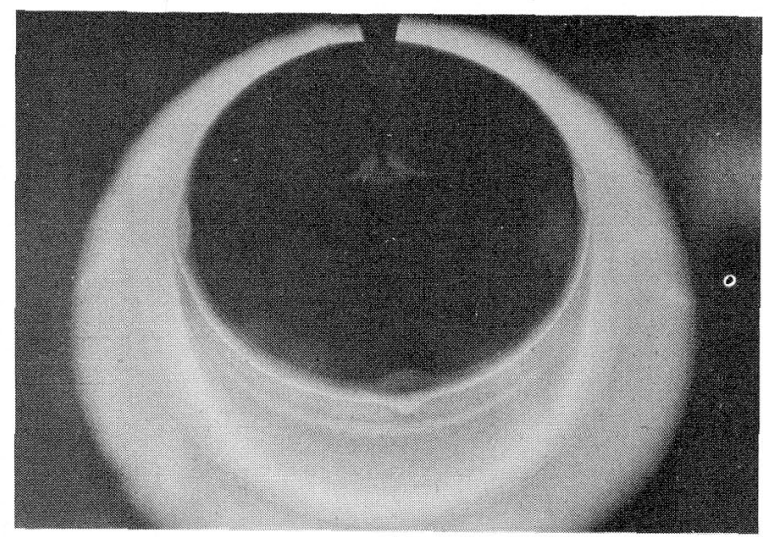

第6図 $C Z$ 法単結晶の成長 
第 1 表 $\quad \mathrm{CZ}$ 結晶と FZ 結晶の特性比較

\begin{tabular}{|c|c|c|c|c|}
\hline 結晶 & \multicolumn{2}{|c|}{$\mathrm{CZ}$} & \multicolumn{2}{|c|}{$\mathrm{FZ}$} \\
\hline 位 & $<111\rangle$ & $\langle 100\rangle$ & $<111>$ & $\langle 100\rangle$ \\
\hline 最 大 直 径 & \multicolumn{2}{|c|}{125 以上 } & 100 & 100 \\
\hline 抵抗率範囲 $\Omega \cdot \mathrm{cm} \begin{array}{l}\mathrm{N} \\
\mathrm{P}\end{array}$ & \multicolumn{2}{|c|}{$\begin{array}{c}0.01 \text { (phos.Sb) }-30 \text { (phos) } \\
0.003(\mathrm{As}) \\
0.005-50(\mathrm{~B})\end{array}$} & \multicolumn{2}{|c|}{$\begin{array}{l}1-500 \text { (phos) } \\
1-3,000^{*} \text { (B) }\end{array}$} \\
\hline $\begin{array}{rr}\text { 成長方向抵抗率変化 } & \mathrm{N} \\
(\%) & \mathrm{P} \\
\end{array}$ & \multicolumn{2}{|c|}{$\begin{array}{l}\text { 大きい } \\
\text { 小さい }\end{array}$} & \multicolumn{2}{|c|}{$\begin{array}{l}\text { 変動あり } \\
\text { な }\end{array}$} \\
\hline $\begin{array}{r}\text { ウx-八内抵抗率変化 (2) } \\
(\%)\end{array}$ & $\begin{aligned} 10 & \sim 30 \\
& \sim 10\end{aligned}$ & $\begin{aligned} & 5 \sim 15 \\
& \sim 10 \\
&\end{aligned}$ & $\begin{aligned} 10 & \sim 40^{[5]} \\
& \sim 10\end{aligned}$ & $\begin{aligned} 5 & \sim 15 \\
& \sim 10\end{aligned}$ \\
\hline $\begin{array}{l}\text { SR法による抵抗率 } \\
\text { (\%) }\end{array}$ & $\begin{aligned} 10 & \sim 40 \\
& \sim 10\end{aligned}$ & $\begin{aligned} 10 & \sim 40 \\
& \sim 10\end{aligned}$ & $\begin{aligned} 30 & \sim 90^{[10]} \\
& \sim 20\end{aligned}$ & $\begin{aligned} 30 & \sim 90 \\
& \sim 20\end{aligned}$ \\
\hline $\begin{array}{l}\text { 転位密度 }{ }^{(4)}\left(\times 10^{3} / \mathrm{cm}^{2}\right) \\
\text { スワール欠陥（無転位） }\end{array}$ & \multicolumn{2}{|c|}{$\begin{array}{l}\text { 〜3 } \\
\text { 条件により発生 } \\
\text { 主に熱処理後に発生 }\end{array}$} & \multicolumn{2}{|c|}{$\begin{array}{c}\sim 40 \\
\text { 条件により発生 }\end{array}$} \\
\hline $\begin{array}{l}\text { ライフタイム }\left(\mu_{\mathrm{sec}}\right) \\
\text { 酸素濃 度** }(\mathrm{ppma}) \\
\text { 孷素 }{ }^{* *}(\mathrm{ppma})\end{array}$ & $\begin{array}{r}30 \sim 300(3 \\
10 \\
0 .\end{array}$ & $\begin{array}{l}\mathrm{n} \text { 以上 ) } \\
30 \\
6\end{array}$ & $\begin{array}{r}\text { 有転位 } 50 \sim 50 \\
0.1 \\
0.1\end{array}$ & $\begin{array}{l}10 \cdot \Omega \mathrm{cm} \\
2 \\
3\end{array}$ \\
\hline
\end{tabular}

（1）通常 2 点法で測定 (2) 4 点法による (3) 広がり抵抗法による

(2)(3)はともにウェー八内全点から最大值 $\max$, 最小值 $\min に よ り,(\max -\min / \mathrm{min}) \times$ 100 を用いた値である。

(4) 直径とともに増大するが，ここでは直径 $40 \mathrm{~mm}$ の場合

* 製造法により $10,000 \Omega \cdot \mathrm{cm}$ 以上も可能

** 製造法により検出下限 $0.1 \mathrm{ppma}$ 以下が可能

[ ] は中性子照射結晶の場合

コン融液を形成し, 希望する方向の結晶軸を持つた種結晶をひた し, 種を回転しながらゆつくり引上げ, 種の下に単結晶を太らせ る方法である(第 6 図)。つぎにC Z 法単結晶の製造プロセスを 示す。

原料多結晶シリコン $\rightarrow$ ルボサイズに合わせ所定のサイズにカ ット $\rightarrow$ 多結晶の洗浄 $\rightarrow$ 多結晶をルツボにチャージ(この時製

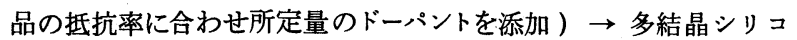
ンの溶融 $\rightarrow$ 種つけ $\rightarrow$ 単結晶化開始 $\rightarrow$ 融液の温度, 引上げ速 度を調節しコーン部の成長 $\rightarrow$ 直胴部の成長 $\rightarrow$ 単結晶を融夜よ り切りはなす $\rightarrow$ 冷却後単結晶を製造機より取り出す $\rightarrow$ 所定の 温度で加熱, 急冷し酸素ドナーを消隇する $\rightarrow$ 中間検査 $\rightarrow$ 加工 工程

$2 \cdot 3 \cdot 4$ 単結晶化工程のまとめ 第 1 表に $\mathrm{C} \mathrm{Z}$ 結晶と $\mathrm{F} \mathrm{Z}$ 結晶の特性比較表を示す。研究開発の具体的内容は刻々变化してき たが, 半導体業界の激しい進歩に応えるためには, 品質の向上, コストダウンに, 常に目を向けている必要がある。品質の向上に ついては, (1)ドーパント以外の不純物量の低減または制御，(2)結 晶性の向上 ( 欠陥のない単結晶 ), (3)狭い範囲で制御されたドー ピングおよび均一のドーピング，(4)物理的(熱的)に強い，等が課 題であり, まだストダウンについては製造装置, 製造技術の改 善が必要であるが, 単結晶棒が長く, 直径の大きいことはコスト ダウンに大きく寄与してきた。これは, ともに時間当りの生産性 の高いためである。現在では, 最大直径 C Zで $125 \mathrm{~mm}, \mathrm{FZ}$ で $100 \mathrm{~mm}$ が製品化されており, 長さにおいても $1 \mathrm{~m}$ 以上の結晶がで きている。直径については最近 10 年間で約 2.5 倍になつている。

電子デバイスの設計上, 二つの方法により製造された単結晶は 同一素子に用いることができるが，実際には不純物特性に違いが あるので素子によつて使い分けされている。 C Z 結晶と F Z 結晶 では製造できる抵抗率範囲が異なる。F Z 法は融体が他の物質に
触れないので，污染がなく高抵抗率結晶の 製造に適している。C Z 法では溶融シリコ ンを形成する石英ルッボからの污染により $50 \Omega \cdot \mathrm{cm}$ 以上の結晶を製造するのは困難で あるが，ドーパント量の多い低抵抗率結晶

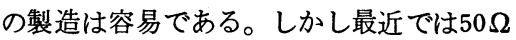
$\mathrm{cm}$ 以上の高抵抗率結晶の要求があり, 現 在研究課題の一つとしてこの問題に取り組 んでいる。結晶内の抵抗率の不均一分布 (ドーパントの不均一分布) は素子特性の 不均一性を意味し, 不均一分布は成長方向 と断面内分布の二つに分けられる。まず成 長方向でみると，F Z 法ではいろいろなド 一パント添加法 (芯ドープ, ガスドープな ぞ）があり，いずれも均一に添加できるが， C Z 法では凝固の特性から, 次第に高濃度 のドーパントが残るため, 成長につれて抵 抗率が低下し, 成長方向に変化が大きい。 一方断面内の抵抗率変化は第 1 表の例に示 すように一般に C Z 結晶より F Z 結晶で大 きい。C Z 結晶における長さ方向, F Z 結 晶における断面内の抵抗率（ドーパント） 分布の均一性について過去約 10 年研究し, 向上してきたが, 未だ不十分であり,この 問題は今後の大きな課題である。

成長中に意図せずに混入する酸素や炭素 は欠陥の発生原因となり，素子特性を損う。 $\mathrm{C} Z$ 法では石英ルッボから融体中に酸素が溶け込み, その結果結 晶内にも〜 $10^{18}$ atoms $/ \mathrm{cc}$ 程度の酸素が取り込まれる。また石英 ルッボの支持体やヒータは黒鉛であり, 雾囲気中に酸素があると 一酸化炭素となり融体中に炭素が取り込まれる。その含有量は極 カさげる必要がある。信越半導体においては, 装置および操業条 件を改善して酸素, 炭素濃度を著しく低減することができ, 特 に昭和 47 年には世界に先駆けて, 単結晶規格の一つとして炭素濃 度を明示した。重金属元素等のドーパント以外の不純物について 述べると, 一般に重金属の偏析係数は極めて小さく $\left(10^{-4} \sim 10^{-5}\right)$, 結晶中に微量しか入らないため, 直接検出するのは困難である。 しかし, 微量でもデバイス特性を左右するため, 従来から少数キ ヤリアのライフタイムの測定により間接的にチェックし, 純度を 保証してきた。しかし, 原料の高純度化, 反応系の高清浄度化, 装置および操業条件の改善により重金属類の污染は非常に少なく なつてきたが, 現在では, 単結晶化後のウェーハ加工工程でこの不 純物を吸収 (ゲッタリング)するような加工方法が ( 背面処理, バックサイド・ダィージ)がとられている。

\section{$2 \cdot 4$ ウェー八加工工程}

できあがつた単結晶棒は中間検査工程に入り, 規定の検査基準 にもとづいて検査する。合格した単結晶棒は次のウェーハ加工工 程に入り, 第 1 図に示した工程で鏡面ウェー八に仕上げられ, 最 終検査に合格したウェーハのみ清浄な容器に包装して製品として 出荷する。

$2 \cdot 4 \cdot 1$ スライス 完成した単結晶棒は, 結晶方位, 不純 物濃度 (抵抗率) , 格子欠陥, 外形寸法などが計測された後, 外 周部と両端部を切断除去する。 O F (Orientated Flat) 加工お よび円筒加工して形状が整えられた単結晶棒は内周式ダイヤモン ドカッターで $0.5 \mathrm{~mm}$ 厚程度に切り出す。I C 用ウェー八は高い平 面度が要求されるためダイヤモンドの微粒子を内周に電着した薄 
い内周刃で正確に切り出す必要がある。

$2 \cdot 4 \cdot 2$ ラッピング スライス後, さらに寸法精度をあげ るため, またスライスによる加工昰を浅く, かつ均一にするため \# 1200 程度の砥粒でラッピングを行なう。次工程, エッチングで このラップ砥粒を除去できるが, 清浄なエッチングウェー八を製 造するには, ラッピング後の洗浄は重要である。

$2 \cdot 4 \cdot 3$ エッチングラッピングされたウェー八は深さ 5 $\sim 10 \mu$ 程度の加工昰が入つているので, この加工雪層を除去する ため, また残留ラップ剂を除去するため, フッ酸一硝酸一酢酸の 混液によりェッチングする。

$2 \cdot 4 \cdot 4$ 研糜(ポリッシング）エッチングされたウェー 八は研摩され完全な鏡面に仕上げられる。研摩法はchemical mecamical polishによつて行なわれ, 表面粗さ $\left(R_{\max }\right)$ は最 大でも $0.1 \mu$ 以下, 最近では $R_{\max } 0.02 \mu$ まで実現されている。最 近は, I C の高集積化にともない, 鏡面の完全性 (結晶加工雪, 污染の全くないこと) はもちろん, 高い水準の平坦度が要求され てきた。これに対応できるように, 研究開発し, 現在では直径 4 in のウェーハで平坦度 (thickness variation) $8 \mu$ が可能 になつた。

$2 \cdot 4 \cdot 5$ 検查, 出荷 超洗浄された鏡面ウェー八は外観, 形状寸法, 鏡面および背面の完全性, 結晶性等を規格にもとづい て検査した後, 合格したウェーハのみ清浄な容器に包装し出荷す る。

\section{3. 結 言}

I C 技術は近年飛躍的に発展し, より高集積化, 応答速度の高 速化に向つて技術革新の真只中である。このため半導体材料メー カとしては, 高品質のシリコン単結晶および污染なく加工された 完全な鏡面, 高い寸法精度, 平坦度 (面粗さも含む) の高水準の 鏡面ウェーハが要求されてきた。この激しく発展する I C 業界に 見合うシリコンウェー八を供給するのは半導体材料メーカとして の使命である。このためにも信越半導体は, 今後さらにたゆまぬ 努力をしていきたいと考えている。

\section{Production of Semiconductor Silicon at Shin-Etsu Handotai Co., Ltd.}

\section{by Naosato YOSHIDA}

Shin-Etsu Handotai Company, Ltd. (SEH) was originally established as a silicon department of Shin-Etsu Chemical Co., Ltd. (SEC). In 1967, being separated from SEC, SEH started as a joint venture between SEC and Dow Corning Corporation. The production originally started at Isobe plant (in Annaka City) and then diversified at other plants as its business grew.

Currently, Isobe Plant manufactures CZ and FZ crystals, epitaxial wafers, and compound semiconductors, while Naoetsu and Takefu Plants manufacture polycrystalline silicon and CZ crystals, respectively. Naoetsu Denshi, Nagano Denshi and SEH Malaysia are specializing in wafer processing so that specialists in each area can work most effectively in improving product quality and increasing production. Currently SEH is the largest supplier of silicon materials in Japan.

Though much technical progress was achieved especially in the polycrystal and CZ operations during the joint venture period, the joint venture with Dow Corning was dissolved in 1979. SEH was re-born as a $100 \%$ owned subsidiary of SEC.

Along with the rapid progress of electronics industry, the requirement for high quality raw materials has become very severe these days. Electronics companies come to ask us to supply perfect crystals (defects free, uniformly doped and highly-pure crystals). The same thing can be said in wafer characteristics; cleanliness, flatness, and perfect surface and shape.

SEH has been very keen to respond to these rapidly changing demands from customers by developing and improving its technologies. Such efforts have brought SEH high reputation and the growing share in both domestic and worldwide markets.

We hope SEH will continue to supply high quality products to our customers, and our basic policy is to manufacture the best quality products at the lowest cost.

製錬 関 係 図書

\begin{tabular}{|c|c|c|c|c|c|c|c|}
\hline$[A]$ & 日本鉱業会関係 & 登行年 & & [A] & 日本鉱業会関係 & 西原分 & \\
\hline & 熔体の物理化学 & 1959 & 350 & & 日本の金銀鉣石＼cjkstart第 1 集 & 1975 & 2,000 \\
\hline & 製鍊排煙の脱硫技術＼cjkstart文献リスト & 1973 & 1,500 & & 日本の金銀鉱石＼cjkstart第 2 集 & 1978 & 3,000 \\
\hline & 非鉄時硫断片集＼cjkstart仲＼cjkstart田 & 1973 & 2,500 & & 訪ポ研修団研修報告 & 1980 & 2,000 \\
\hline & インプレースリーチングＩ & 1974 & 1,600 & [B] & 日本金属学会 & & \\
\hline & インプレースリーチングＩI & 1979 & 1,600 & & 講座・現代の金属学 製鍊編 & \multirow{5}{*}{$\begin{array}{l}1979 \\
1980\end{array}$} & \multirow{5}{*}{$\begin{array}{c}\text { (会員価) } \\
2,400 \\
2,200\end{array}$} \\
\hline & インプレースリーチング海外調査報告 & 1975 & 2,500 & & 第 1 巻 鉄鋼製鍊 & & \\
\hline & インプレースリーチング海外調査報告ＩI & 1977 & 2,000 & & 第 2 巻 非鉄金属製鍊 & & \\
\hline & $\begin{array}{l}\text { 有価金属のインブレースリーチング技術 } \\
\text { 研究報書 } 53 \text { 年度成果報告. }\end{array}$ & 1979 & 2,500 & & 第 3 巻 冶金熱工学 & & \\
\hline & 有価金属のインプレースリーチング技術 & 1980 & 2000 & & 冶金物理化学 & & \\
\hline & 研究報告書５4 年度成果報告 & & & [C] & 日本鉛亜鉛需要研究会 & & \\
\hline & アグロメレーション 上巻 & 1974 & 2,000 & & \multirow[b]{2}{*}{ 鉛ハンドブック } & & \\
\hline & アグロメレーション 下巻 & 1977 & 1,800 & & & 1975 & 1,500 \\
\hline & 湿式製鍊技術 & 1977 & 2,200 & & 鉛の耐食性 & 1976 & 1,000 \\
\hline & 錫 製 鍊 渡 辺 元 雄著 & 1979 & 5,000 & & \multirow{3}{*}{$\begin{array}{l}\text { 亜鉛ハンドブック } \\
\text { 亜鉛ダイガストハンドブック } \\
\text { 要鉛とその耐食性 }\end{array}$} & 1977 & 3,500 \\
\hline & 最近の亜鉛製鍊の進歩と展望 & 1981 & 3,500 & & & 1974 & 2,000 \\
\hline & 製銇硫黄の新しい固定法 & 1981 & 2,000 & & & 1974 & 1,000 \\
\hline
\end{tabular}

（）上記図書の他に，本会会誌，本会秋季大会分科研究会資料もお頒けします。「文献集」ご参照の上，お申込み下さい。 ○ご購入の節は, 日本鉱業会まで書面でお申込み下さい。請求書を同封お送りいたします。 